\title{
Prevalence of sarcopenia in kidney transplants and their association with determinant factors of muscle homeostasis
}

\author{
(iD) Cleodice Alves Martins ${ }^{1}$ \\ - Ana Karina Teixeira da Cunha França ${ }^{2-3}$ \\ (iD) Raimunda Sheyla Carneiro Dias ${ }^{4}$ \\ (iD) Rayanna Cadilhe de Oliveira Costa ${ }^{1}$ \\ Antônio Pedro Leite Lemos ${ }^{1}$ \\ (iD) Alcione Miranda dos Santos ${ }^{3}$ \\ (iD) Elane Viana Hortegal ${ }^{2-3}$ \\ (iD) Dyego José de Araújo Brito ${ }^{4}$
}

1. Universidade Federal do Maranhão, Hospital Universitário Presidente Dutra, Programa de Residência Multiprofissional em Saúde, São Luis, MA, Brasil 2. Universidade Federal do Maranhão, Departamento de Ciências Fisiológicas, Curso de Nutrição, São Luis, MA, Brasil 3. Universidade Federal do Maranhão, Programa de Pós-Graduação em Saúde Coletiva, São Luis, MA, Brasil 4. Universidade Federal do Maranhão, Hospital Universitário Presidente Dutra, Serviço de Nefrologia, São Luis, MA, Brasil

\section{SUMMARY}

INTRODUCTION: Sarcopenia is characterized by the involuntary loss of lean body mass associated with a progressive reduction of muscle strength.

OBJECTIVE: To determine the prevalence of sarcopenia in kidney transplant recipients and its association with the determining factors that control muscle homeostasis.

METHODS: We evaluated renal transplant recipients undergoing follow-up at the University Hospital of the Federal University of Maranhão from June 2017 to July 2018 and who met the inclusion criteria. Sarcopenia was defined according to the European criteria. The skeletal muscle mass index was measured by dual-energy radiological absorptiometry; the values $<7,26 \mathrm{~kg} / \mathrm{m}^{2}$ for men and $<5,5 \mathrm{~kg} / \mathrm{m}^{2}$ for women were adopted for muscle depletion. For handgrip strength, values of $<30 \mathrm{~kg}$ for men and $<20 \mathrm{~kg}$ for women were considered as reduced muscle strength. In both sexes, the cutoff point for walking speed was $<0,8 \mathrm{~m} / \mathrm{s}$.

RESULTS: We evaluated 83 renal transplant recipients with a mean age of $48.8 \pm 12,1$ years and predominantly males (57,8\%). The prevalence of sarcopenia was 19,3\%. Among individuals without sarcopenia, 17,9\% had a decrease in handgrip strength and 40,3\% has altered gait speed.

DISCUSSION: Individuals submitted to renal transplant may develop sarcopenia while still young and already present altered muscle function and strength even before the depletion of lean body mass.

CONCLUSION: Early diagnosis may allow the prevention of sarcopenia and provide a better quality of life for patients.

KEYWORDS: Kidney transplantation. Sarcopenia. Muscle strength. 


\section{INTRODUCTION}

Sarcopenia is a syndrome characterized by the involuntary loss of lean body mass (LBM) associated with a reduction of its strength and function and is a frequent change that accompanies the physiological process of aging. Although sarcopenia is usually associated with advanced age, it can accompany various chronic diseases in younger patients ${ }^{\mathbf{1}}$.

In chronic kidney disease (CKD), sarcopenia is associated with the results of a change in the balance between catabolism and anabolism that controls the homeostasis of muscles' ${ }^{1}$. In individuals with CKD, sarcopenia promotes the loss of muscle strength already at the moment of conservative treatment and progresses with the loss of renal function' ${ }^{1}$ In CKD, sarcopenia increases morbidity ${ }^{1}$ and is strongly correlated with higher mortality, physical disability ${ }^{2}$, and increased cardiovascular events ${ }^{3}$.

When there is kidney failure, among the possible renal replacement therapies (RRT), transplant emerges as the best option ${ }^{4}$. Sarcopenia in renal-transplant patients (RxT) has been studied in recent years; however, the literature is still scarce.

Considering the association of sarcopenia with adverse events and that it can occur very early in individuals with CKD, impacting their prognosis and survival, the objective of this study was to determine the prevalence of sarcopenia in renal-transplant patients (RxT) and its association with the determining factors that control muscle homeostasis.

\section{METHODS}

This is a cross-sectional study conducted on RxT at the Center for Kidney Disease Prevention of the University Hospital of the Federal University of Maranhão (HUUFMA), from June 2017 to July 2018. This study was part of a larger study, entitled "Nutritional Status of Renal Transplant Patients in The State of Maranhão", which was approved by the Human Research Ethics Committee of HUUFMA(Opinion no 1.872.021).

Variables were used to calculate the sample size, with its upper and lower limits defined by tolerance and characterized by a measure defined by a number, based on unpaired data, considering there was no control group. The study was completed in 213 individuals. The following were adopted as inclusion criteria: individuals aged above 20 years, of both sexes, RxT, undergoing outpatient follow-up on
HUUFMA. We did not include pregnant women and people with amputated limbs, suffering from neurological diseases or sequelae from cerebrovascular accidents who were predisposed to a reduction of handgrip strength (HGS) or cognitive impairment, in addition to those with contagious or chronic consumptive diseases. Thus, the final sample comprised 83 individuals who met the criteria. All those who agreed to participate in the study signed an informed consent form.

We adopted two classifications for Body Mass Index (BMI): the one proposed for adults by the World Health Organization ${ }^{5}$ and Lipschitz ${ }^{6}$ for the elderly. The distribution of abdominal fat was assessed by waist circumference (WC) ${ }^{7}$.

Sarcopenia was defined per the criteria of the European Working Group on Sarcopenia in Older People (EWGSOP) ${ }^{8}$. For the assessment of body composition, patients were submitted to densitometry tomography by dual-energy x-ray absorptiometry (DEXA). To determine the LBM, the relative skeletal muscle index (RSMI) was measured according to the criteria established by Baumgartner and defended by the European Working Group on Sarcopenia in Older People. ${ }^{8}$ The State of LBM decrease was assigned to cases in which the RSMI values were lower than $7.26 \mathrm{~kg} / \mathrm{m}^{2}$ for men and $5.5 \mathrm{~kg} / \mathrm{m}^{2}$ for women.

The handgrip strength (HGS) was used to assess muscle strength. The cut-off point was $<30 \mathrm{~kg}$ for men and $<20 \mathrm{~kg}$ for women. ${ }^{8}$

Muscle performance was assessed by calculating the gait speed test. A speed of less than $0.8 \mathrm{~m} / \mathrm{s}$ was considered a risk for sarcopenia. ${ }^{8}$

\section{Data Analysis}

The categorical variables were presented through frequencies and percentages, and quantitative variables, based on mean and standard deviation values (mean $\pm \mathrm{SD}$ ). The normality of the variables was tested by the Shapiro-Wilk test. The analysis of numerical variables by the presence of sarcopenia was carried out by student t-test for variables with normal distribution and Mann Whitney test for the others. The analysis of categorical variables by the presence of sarcopenia was carried out using the chisquare test. We adopted a $95 \%$ confidence interval (1.96 standard deviation and standard error of 5\%). Analyses were made using the Stata software, version $14.0^{\circledR}$. 


\section{RESULTS}

We assessed 83 RxT (mean age $48.8 \pm 12.1$ years). The prevalence of sarcopenia was $19.3 \%$. Adult patients with and without sarcopenia had a mean BMI in the range of eutrophy, but with a statistically significant difference $\left(24.7 \pm 4.9 \mathrm{~kg} / \mathrm{m}^{2}\right.$ vs $19.1 \pm 2.4 \mathrm{~kg} / \mathrm{m} 2$, respectively; $p$-value $=0.018)$. Whereas elderly individuals without sarcopenia presented mean BMI values in the range of excess body weight $\left(28.3 \pm 4.3 \mathrm{~kg} / \mathrm{m}^{2}\right)$, while those with sarcopenia were in the range of eutrophy $\left(24.3 \pm 8.4 \mathrm{~kg} / \mathrm{m}^{2}\right)$; however no statistical difference was observed ( $p$-value $=0.070$ ).

The mean values of the WC of the men and women showed a high risk for cardiovascular diseases for those without sarcopenia $(94.6 \pm 11.9 \mathrm{~cm}$ and $87.5 \pm 13,6$ $\mathrm{cm}$, respectively) and low risk for those with sarcopenia $(82.5 \pm 13.7 \mathrm{~cm}$ and $77.9 \pm 20.6 \mathrm{~cm}$, respectively), but with a statistically significant difference only among men (p-value $=0.007)$ (Table 2).

Men and women without sarcopenia also showed preserved $\left(08.1 \pm 0.8 \mathrm{~kg} / \mathrm{m}^{2}\right.$ and $6.6 \pm 0.7 \mathrm{~kg} / \mathrm{m} 2$, respectively) and significantly higher (p-value $<0.001)$ mean values of LBM when compared to the group with sarcopenia $\left(6.7 \pm 0.4 \mathrm{~kg} / \mathrm{m}^{2}\right.$ and $5.2 \pm 0.3 \mathrm{~kg} / \mathrm{m} 2$, respectively), which were altered (Table 2).

The gait test showed an alteration for both groups assessed, but with a greater reduction of muscle performance in individuals with sarcopenia $(0.74 \pm 0.17 \mathrm{~m} / \mathrm{s}$ vs $0.68 \pm 0.40 \mathrm{~m} / \mathrm{s}$; p-value=0.009). HGS
TABLE 2. CLINICAL, ANTHROPOMETRIC, AND BIOCHEMICAL CHARACTERISTICS AND COMPARISON BETWEEN WITH SARCOPENIA AND WITHOUT SARCOPENIA IN THE POPULATION STUDIED, SÃO LUÍS - MA, 2019.

\begin{tabular}{|c|c|c|c|}
\hline Variable & $\begin{array}{l}\text { Without } \\
\text { sarcopenia } \\
\text { Mean } \pm \text { SD }\end{array}$ & $\begin{array}{l}\text { With sarco- } \\
\text { penia } \\
\text { Mean } \pm \text { SD }\end{array}$ & $\mathrm{p}$-value \\
\hline Age (years) & $49.4 \pm 1.4$ & $46.1 \pm 3.6$ & 0.463 \\
\hline \multicolumn{4}{|l|}{ BMI $\left(\mathrm{kg} / \mathrm{m}^{2}\right)$} \\
\hline Adults & $24.7 \pm 4.9$ & $19.1 \pm 2.4$ & 0.018 \\
\hline Elderly & $28.3 \pm 4.3$ & $24.3 \pm 8.4$ & 0.070 \\
\hline $\begin{array}{l}\text { WC }(\mathrm{cm}) \\
\text { Men } \\
\text { Women }\end{array}$ & $\begin{array}{l}94.6 \pm 11.9 \\
87.5 \pm 13.6\end{array}$ & $\begin{array}{l}82.5 \pm 13.7 \\
77.9 \pm 20.6\end{array}$ & $\begin{array}{l}0.007 \\
0.161\end{array}$ \\
\hline $\begin{array}{l}\text { Lean Body Mass }\left(\mathrm{kg} / \mathrm{m}^{2}\right) \\
\text { Men } \\
\text { Women }\end{array}$ & $\begin{array}{l}8.1 \pm 0.8 \\
6.6 \pm 0.7\end{array}$ & $\begin{array}{l}6.7 \pm 0.4 \\
5.2 \pm 0.3\end{array}$ & $\begin{array}{l}<0.001 \\
<0.001\end{array}$ \\
\hline Gait Test $(\mathrm{m} / \mathrm{s})$ & $0.74 \pm 0.17$ & $0.68 \pm 0.40$ & 0.009 \\
\hline $\begin{array}{l}\text { Hand Grip Strength (kg) } \\
\text { Men } \\
\text { Women }\end{array}$ & $\begin{array}{l}30.6 \pm 8.7 \\
19.7 \pm 3.2\end{array}$ & $\begin{array}{l}25.0 \pm 4.9 \\
18.7 \pm 3.7\end{array}$ & $\begin{array}{l}0.021 \\
0.476\end{array}$ \\
\hline Transplant Time (months) & $65.4 \pm 54.3$ & $60.3 \pm 61.7$ & 0.503 \\
\hline Albumin (g/dL) & $4.3 \pm 0.4$ & $4.3 \pm 0.4$ & 0.910 \\
\hline Hemoglobin (mg/dL) & $12.78 \pm 1.59$ & $12.36 \pm 1.64$ & 0.356 \\
\hline Total cholesterol (mg/dL) & $165.9 \pm 38.1$ & $175.3 \pm 37.3$ & 0.393 \\
\hline $\mathrm{HDL}-\mathrm{c}(\mathrm{mg} / \mathrm{dL})$ & $50.3 \pm 17.9$ & $47.7 \pm 16.8$ & 0.662 \\
\hline $\mathrm{LDL}-\mathrm{c}(\mathrm{mg} / \mathrm{dL})$ & $84.7 \pm 33.2$ & $88.7 \pm 19.3$ & 0.715 \\
\hline Triglycerides (mg/dL) & $173.7 \pm 110.1$ & $157.3 \pm 74.7$ & 0.586 \\
\hline Blood Glucose (mg/dL) & $106.3 \pm 41.5$ & $93.1 \pm 27.2$ & 0.231 \\
\hline Serum Creatinine (mg/dL) & $1.50 \pm 0.97$ & $1.56 \pm 0.60$ & 0.832 \\
\hline $\begin{array}{l}\text { Cclearance Creatinine } \\
\left(\mathrm{ml} / \mathrm{min} / 1.73^{2}\right)\end{array}$ & $58.9 \pm 19.7$ & $55.9 \pm 23.5$ & 0.601 \\
\hline
\end{tabular}

FIGURE 1. ALTERED CRITERIA FOR CHARACTERIZING SARCOPENIA IN THE POPULATION STUDIED, SÃO LUÍS - MA, 2019.

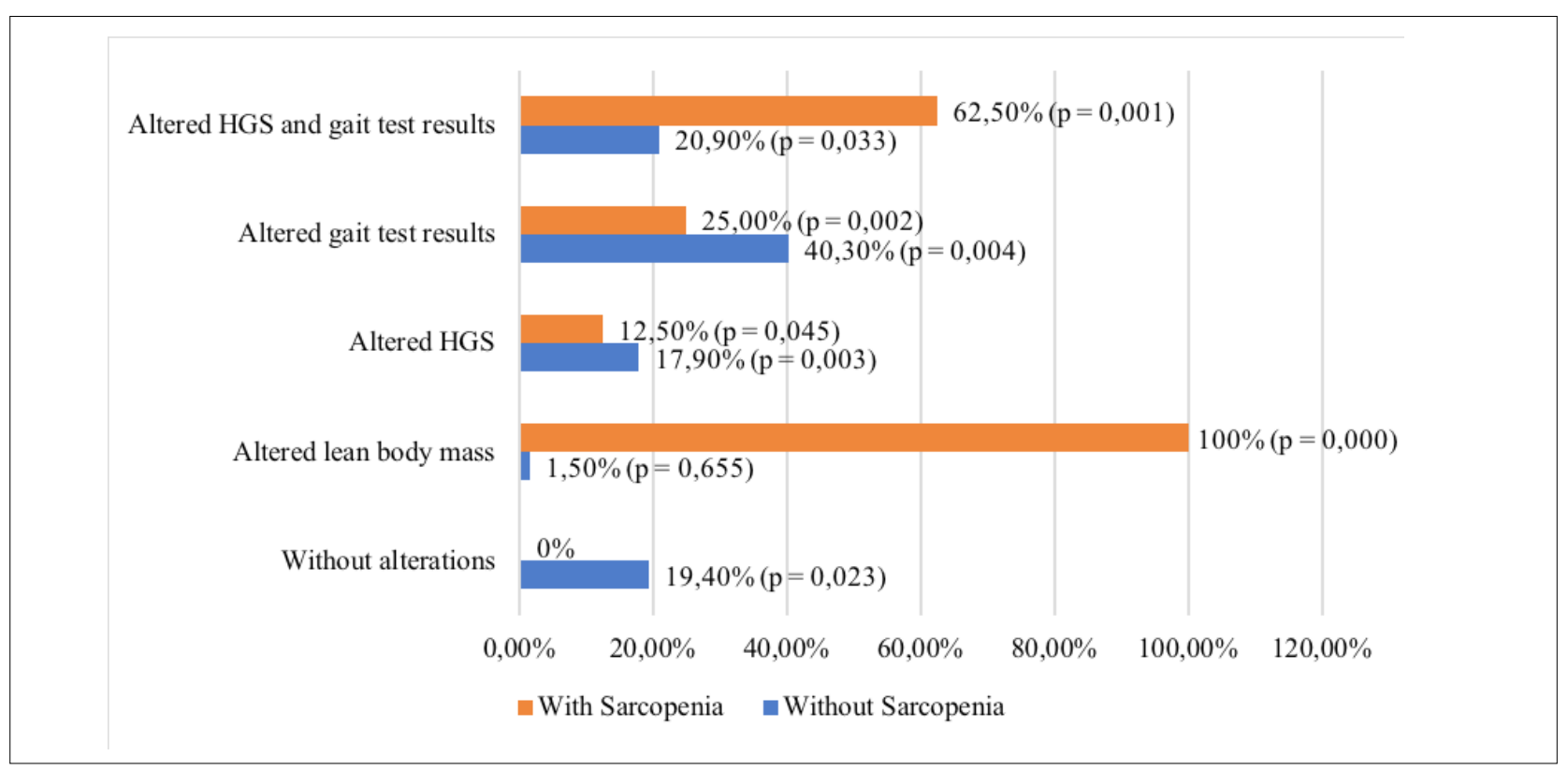


TABLE 1. SOCIODEMOGRAPHIC, CLINICAL AND NUTRITIONAL CHARACTERISTICS OF THE POPULATION STUDIED, SÃO LUÍS - MA, 2019

\begin{tabular}{|c|c|c|}
\hline Variables & $\mathrm{N}$ & $\%$ \\
\hline \multicolumn{3}{|l|}{ Sex } \\
\hline Female & 35 & 42.2 \\
\hline Male & 48 & 57.8 \\
\hline \multicolumn{3}{|l|}{ Age range } \\
\hline$\geq 20<40$ years & 19 & 22.9 \\
\hline$\geq 40<60$ years & 49 & 59.0 \\
\hline$\geq 60$ years & 15 & 18.1 \\
\hline \multicolumn{3}{|l|}{ Color } \\
\hline White & 8 & 9.6 \\
\hline Black & 17 & 20.5 \\
\hline Brown & 55 & 66.3 \\
\hline Others & 3 & 3.6 \\
\hline \multicolumn{3}{|l|}{ Income } \\
\hline$>1 \mathrm{MW}$ & 3 & 3.6 \\
\hline 1 to $2 \mathrm{MW}$ & 44 & 53.1 \\
\hline 2 to $4 \mathrm{MW}$ & 23 & 27.7 \\
\hline$\geq 4 \mathrm{MW}$ & 13 & 15.6 \\
\hline \multicolumn{3}{|l|}{ Formal education } \\
\hline$\leq 9$ years & 30 & 36.1 \\
\hline$>9$ years & 53 & 63.9 \\
\hline \multicolumn{3}{|l|}{ Alcohol Consumption } \\
\hline No former consumption & 76 & 91.6 \\
\hline Yes & 7 & 8.4 \\
\hline \multicolumn{3}{|l|}{ Smoking } \\
\hline Not a former smoker & 83 & 100.0 \\
\hline \multicolumn{3}{|l|}{ Type of donor } \\
\hline Living & 38 & 45.8 \\
\hline Deceased & 45 & 54.2 \\
\hline \multicolumn{3}{|l|}{ RxT Time } \\
\hline$<6$ months and $<1$ year & 14 & 16.9 \\
\hline$\geq 1$ year and $<3$ years & 24 & 28.9 \\
\hline$\geq 3$ years and $<5$ years & 11 & 13.2 \\
\hline$\geq 5$ years & 34 & 41.0 \\
\hline \multicolumn{3}{|l|}{ Diabetes } \\
\hline Present & 13 & 16.2 \\
\hline \multicolumn{3}{|l|}{ Hypertension } \\
\hline Present & 70 & 87.5 \\
\hline \multicolumn{3}{|l|}{ Sarcopenia } \\
\hline Present & 16 & 19.3 \\
\hline \multicolumn{3}{|l|}{$\mathrm{BMI}$} \\
\hline Low weight & 6 & 7.2 \\
\hline Eutrophy & 29 & 34.9 \\
\hline Overweight & 32 & 38.5 \\
\hline Obesity & 16 & 19.4 \\
\hline
\end{tabular}

was reduced only in men with sarcopenia $(25.0 \pm$ $4.9 \mathrm{~kg}$ ), with a statistically significant difference (p-value=0.021) when compared to those without sarcopenia. On the other hand, for women, HGS was reduced in both groups $(19.7 \pm 3.2 \mathrm{~kg}$ and $18.7 \pm 3.7 \mathrm{~kg}$; p-value $=0.476$ ) (Table 2).

Based on the analysis of the criteria for characterizing sarcopenia, it is possible to observe that among RxT patients with sarcopenia,12.5\% presented decreased HGS ( $p$-value $=0.045), 25.0 \%$ altered gait test results $(p$-value $=0.002)$, and $62.5 \%$ altered HGS and gait test results ( $p$-value $=0.001)$. It is worth noting that, although only $1.5 \%$ of the cases without sarcopenia presented decreased lean body mass ( $p$-value $=0.655), 17.9 \%$ had decreased HGS ( $p$-value $=0.003)$, $40.3 \%$ altered gait test results ( $p$-value $=0.004)$, and $20.9 \%$ had both criteria altered (p-value=0.033) (Figure 1).

\section{DISCUSSION}

Studies on RxT indicate that sarcopenia occurs in younger age in comparison to the general population. ${ }^{5,8-10}$ The only study conducted on RxT in Brasil found that the prevalence of this syndrome was more than double $(49.6 \%)^{11}$, the highest percentage up until now reported in the literature. It is likely that sarcopenia in CKD starts during the period of conservative treatment, progressing with the loss of renal function and increasing morbidity. ${ }^{1}$

The prevalence of sarcopenia can also vary as a result of the methodology employed in its characterization since there is no universal operational definition and/or diagnostic criteria. In addition, the characteristics of the studied population can also interfere in the prevalence of sarcopenia since many factors lead to its development and progression, including advanced age, sedentary lifestyle, prolonged hospitalization, insulin resistance in the general population, among others. ${ }^{8}$

The BMI, in more than half of the sample (57.9\%), remained in the range of overweight and obesity. It is worth noting that the index is not reliable regarding the differentiation of body fat (BF) and LBM, since throughout our lives can we maintain a stable weight and slowly lose LBM, gaining BF in equal volume, thus maintaining the same BMI for years; something that actually occurs in many people. In addition, sarcopenia can be difficult to identify, making it crucial to use other measurements that identify LBM. ${ }^{12}$ We suppose that the weight gain in $\mathrm{RxT}$ is a result of several factors, such as recovery from anemia, a better quality of life, and increased appetite caused by the administration of steroids and immunosuppressants. ${ }^{13}$ 
Considering the above, it is necessary to raise questions about the quality of the diet of RxT, since this population is considered high risk for the development of obesity and changes in lipid and blood glucose metabolism due to the use of immunosuppressant drugs and the increased dietary freedom since dietary restrictions decrease dramatically post-transplant. The diet of a RxT individual is similar to that of a healthy one, without marked restrictions for sodium, phosphorus, and potassium, which causes this population to eat, in the postoperative stage, without pondering current and future complications, after all, they have gone through periods of dietary restriction. ${ }^{14}$

However, despite this share of RxT with excess weight and the preserved LBM, even in those without sarcopenia impaired HGS and gait were observed. According to findings of other studies, HGS was reduced in $40 \%$ of RxT. $^{4}$ There is already evidence of a dissociation between muscle mass and strength; the decline in HGS seems to be faster than the concomitant loss of LBM. ${ }^{15}$

This study presented as a limitation its cross-sectional design and the lack of assessment of adherence to the diet in the population studied. On the other hand, it presented as a strong point the assessment of sarcopenia in a population more susceptible to nutritional changes. In addition, we used the DEXA, considered the gold standard for assessing muscle mass with greater precision. Additionally, the research was carried out in a reference hospital for RxT in the state of Maranhão, the only center for renal transplant patient follow-up in the state.

\section{CONCLUSIONS}

Sarcopenia can develop in younger ages in RxT, and muscle strength and gait test results can be reduced even before a decrease in LBM. Another fact evidenced in this study was the prevalence of excess weight in this population, reinforcing the concern with the quality of the diet after RxT, since dietary restrictions decrease and these individuals have greater freedom in their food choices. This reinforces the importance of a thorough assessment of nutritional status in these patients, considering the differentiation of body composition and evaluating the individual holistically. Therefore, early diagnosis of the syndrome may allow for more rapid and effective intervention in RxT, preventing mobility disorders, falls, functional disability, and worsening of quality of life.

\section{Author's Contribution}

Cleodice Alves Martins and Ana Karina Teixeira da Cunha Françacontributed significantly in all stages of the project. The other authors contributed in data collection or analysis and interpretation and in the approval of the final version of the text.

\section{Funding}

Fundação de Amparo à Pesquisa e ao Desenvolvimento Científico e Tecnológico do Maranhão - Fapema (Universal-00683/18). Institution where the work was carried out: Centro de Prevenção de Doenças Renais Hospital Universitário da Universidade Federal do Maranhão (HUUFMA).

\section{RESUMO}

INTRODUÇão: A sarcopenia é caracterizada pela perda involuntária da massa magra associada à redução da força e função muscular, de modo progressivo.

OBJETIVO: Determinar a prevalência de sarcopenia em transplantados renais e sua associação com os fatores determinantes que controlam a homeostase do músculo.

MÉTODOS: Foram avaliados indivíduos transplantados renais em acompanhamento no Hospital Universitário da Universidade Federal do Maranhão no período de junho de 2017 a julho de 2018 e que preencheram os critérios. A sarcopenia foi definida de acordo com o critério europeu. $O$ índice de massa muscular esquelética foi medido por meio da densitometria computadorizada por absorciometria radiológica de dupla energia; valores $<7,26 \mathrm{~kg} / \mathrm{m}^{2}$ para homens e $<5,5 \mathrm{~kg} / \mathrm{m}^{2}$ para mulheres foram adotados para depleção muscular. Para força de preensão manual, valores de $<30 \mathrm{~kg}$ para homens e $<20 \mathrm{~kg}$ para mulheres foram considerados como redução da força muscular. Em ambos os sexos, o ponto de corte para velocidade de marcha reduzida foi $<0,8 \mathrm{~m} / \mathrm{s}$.

RESULTADOS: Foram avaliados 83 transplantados renais, com média de idade de 48,8 12,1 anos e predominância de indivíduos do sexo masculino (57,8\%). A prevalência de sarcopenia foi de 19,3\%. Entre os indivíduos sem sarcopenia, 17,9\% já tinham diminuição da força de preensão manual e 40,3\%, alteração do teste de marcha.

DISCUSSÃo: Indivíduos submetidos ao transplante renal podem desenvolver sarcopenia jovens e apresentar alteração da função e da força muscular mesmo antes da depleção da massa magra.

CONCLUSÃO: O diagnóstico precoce pode permitir a prevenção da sarcopenia e propiciar melhor qualidade de vida aos pacientes. PALAVRAS-CHAVE: Transplante de rim. Sarcopenia. Força muscular. 


\section{REFERENCES}

1. Domański M, Ciechanowski K. Sarcopenia: a major challenge in elderly patients with end-stage renal disease. J Aging Res. 2012;2012:754739.

2. Cusumano AM. Sarcopenia en pacientes con y sin insuficiencia renal crónica: diagnóstico, evaluación y tratamento. Nefrologia, diálisis y transplante. 2015;35(1):32-43.

3. Yanishi M, Kimura Y, Tsukaguchi H, Koito Y, Taniguchi H, Mishima T, et al. Factors associated with the development of sarcopenia in kidney transplant recipientes. Tranplant Proc. 2017;49(2):288-92.

4. Malgorzewicz S, Woloszyk P, Chamienia A, Dębska-Ślizień A. The prevalence of sarcopenia in kidney transplant recipientes. Nephrology Dialysis Tranplantation. 2018;33(suppl. 1):i585.

5. World Health Organization. Obesity: preventing and managing the global epidemic. Geneva: World Health Organization; 1998.

6. Lipschitz DA. Screening for nutritional status in the elderly. Prim Care. 1994;21(1):55-67.

7. World Health Organization. Physical status: the use and interpretation of anthropometry. Report of a WHO Expert Committee. Geneva: World Health Organization; 2000.

8. Cruz-Jentoft AJ, Baeyens JP, Bauer JM, Boirie Y, Cederholm T, Landi F, et al; European Working Group on Sarcopenia in Older People. Sarcopenia: European consensus on definition and diagnosis: report of the European Working Group on Sarcopenia in Older People. Age Ageing. 2010;39(4):412-23.
9. Baumgartner RN, Koehler KM, Gallagher D, Romero L, Heymsfield SB, Ross $\mathrm{RR}$, et al. Epidemiology of sarcopenia among the elderly in New Mexico. Am J Epidemiol. 1998;147(8):755-63.

10. Garcia PK, Gélvez IS, Navarro K, Contreras K, Rodríguez MP, González C. Prevalencia de síndrome metabólico y relación con eventos cardiovasculares, supervivencia y función del injerto en pacientes con transplante renal. Rev Colomb Cardiol. 2017;24(6):545-9.

11. Reis AS, Santos HO, Limirio LS, Oliveira EP. Phase angle is associated with handgrip strenght but not with sarcopenia in kidney transplantation patients. J Ren Nutr. 2019;29(3):196-204.

12. Gürlek Demirci B, Sezer S, Tutal E, Çolak T, Uyanık S, Haberal M. Handgrip strength is associated with serum testosterone and albumin levels in male kidney transplant recipientes. Exp Clin Transplant. 2018;16(Suppl 1):75-9.

13. Diz JB, Leopoldino AA, Moreira BS, Henschke N, Dias RC, Pereira LS, et al. Prevalence of sarcopenia in older Brazilians: a systematic review and meta-analysis. Geriatr Gerontol Int. 2017;17(1):5-16.

14. Teixeira AP, Fernandes NM, Mata GF, Chaoubah A, Paula RB, Bastos MG. Prevalence of metabolic syndrome and its associated factors in renal transplant recipientes. J Bras Nefrol. 2012;34(1):16-21.

15. Manini TM, Clark BC. Dynapenia and aging: an update. J Gerontol A Biol Sci Med Sci. 2012;67(1):28-40. 